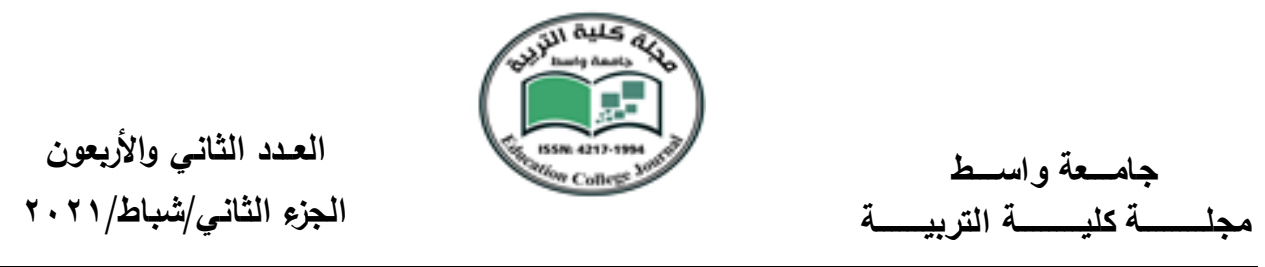

\title{
التحليل الصرفيّ للألغاز والأحاجي اللغويّة
}

أ.م.د عبد الرضا جواد حيال

كلية الكوت الجامعة /العرلق/ واسط أرطال

Jaiuwudh23@gmail.com

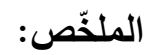

الألغاز في الصرف العربيّ توصف بأنها أعقد أنواع الألغاز في اللغة العربية؛ لأنّ اللغز نفسه فيه

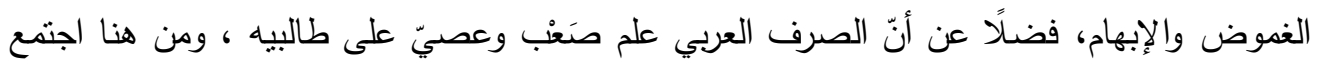

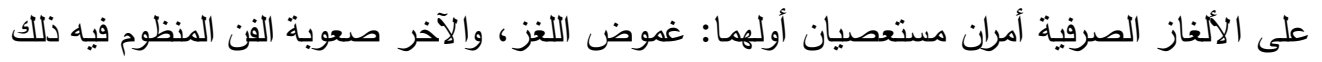
• اللغز

وهذه الدراسة تكثف اللثام عن هذين الأمرين المستعصيين بالدرس، والتحليل بجملة من الألغاز الصرفية في اللغة العربية.

الكلمات المفتاحية: الصرف، الألغاز، الأحاجي

\section{Morphological analysis of puzdles are riddles}

\section{Assistant Prof. Abdul-Reda. J.Hiyal}

Al Kut University College.Wasit/ Iraq

\section{Jaiuwudh23@gmail.com}

\section{Summary:}

Puzzles in the arabic morphology is described as the most complex puzzles in the Arabic language, It's because that the same puzzle has it's mysteries and vagueness, Other than the fact that the arabic morphology is a difficult science and isn't easy to it's students, and it has been agreed upon that to the morphological puzzles two difficult things, first of which is the mystery of the puzzle, secondly is the difficulty of the art that the puzzle is portrayed as. And this study unveils these two different subjects, and analyzing a sentence of the morphological puzzles in the arabic language.

Key words: Exchange, Riddles, Puzzles 
العدد الثاني والأربعون

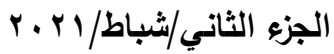

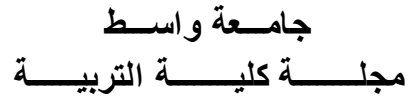

المقدمة:

بسم الهه الرحمن الرحيم

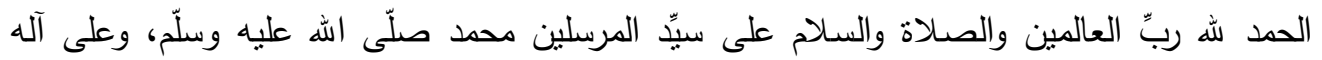
وصحبه أجمين. وبعد

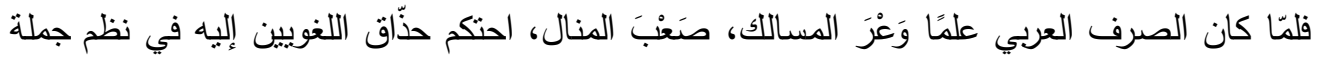

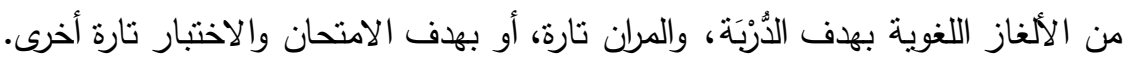

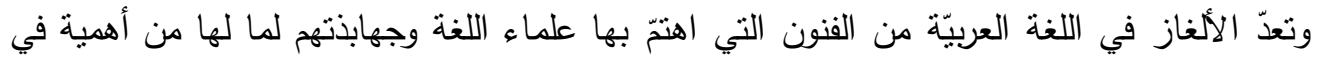

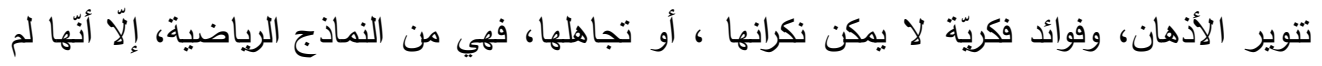

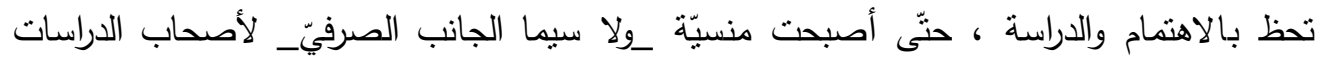

الحديثة.

فالألغاز تحتاج إلى التتقيب ، والبحث عنها في كتب الأقدمين، وإظهارها لترى النور لَِّّا لها من القيم التعليميّة التطبيقيّة لدى المختصن. قد حظي موضوع الألغاز النحويّة والصرفيّة بعناية اللغويين، فألفوا فيه كتبًا منهم: أبو نصر

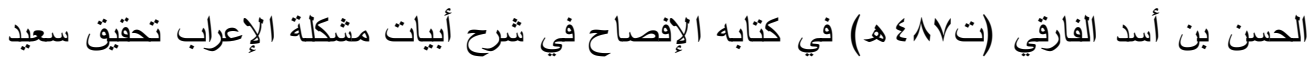

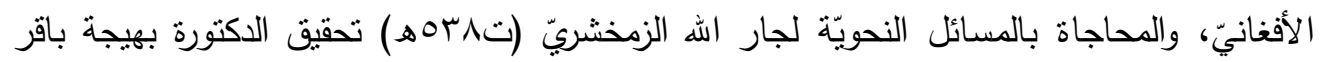

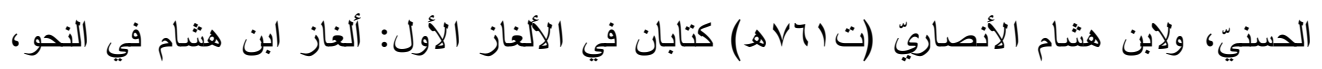

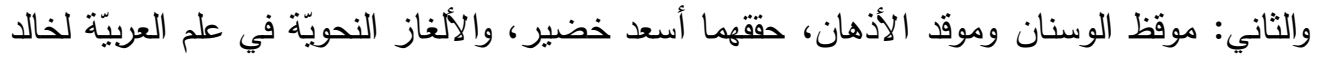

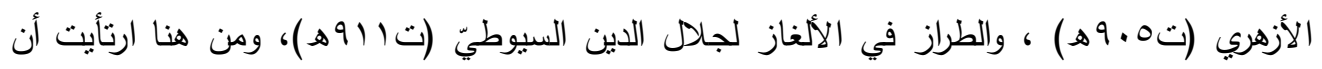

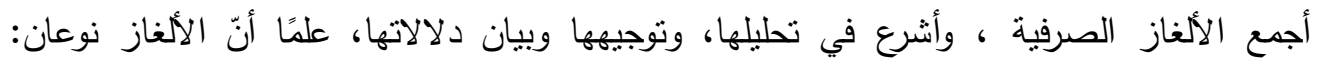

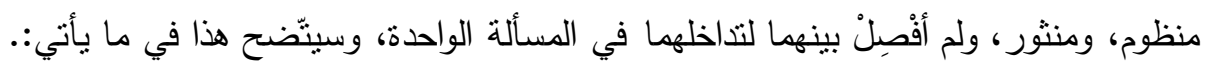

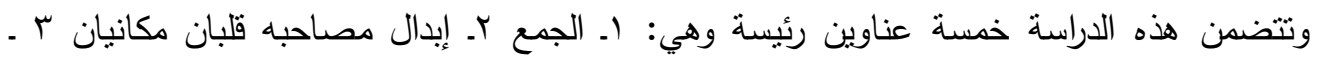

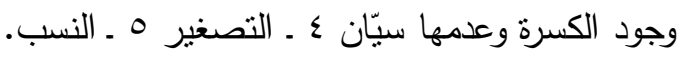

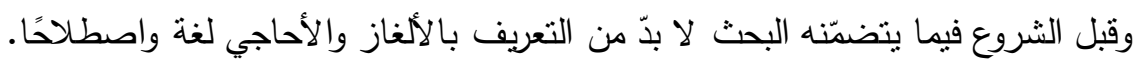


العدد الثاني والأربعون

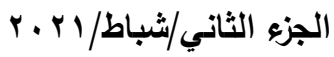

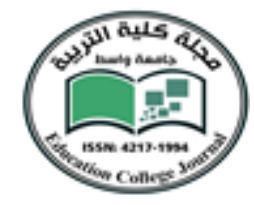

الألغاز والأحاجي لغة واصطلاحًا:

الألغاز مفرد لُغزز - بضم أوله وسكون ثانية - ولُغَزَ - بضم الأول وفتح الثاني - ولَغَز - بفتحح

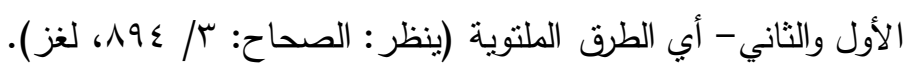

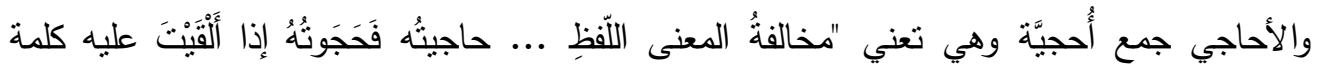

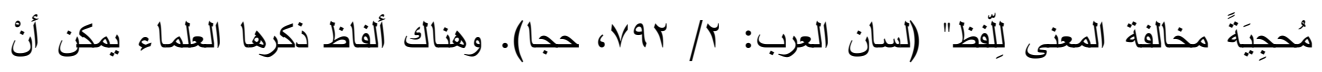

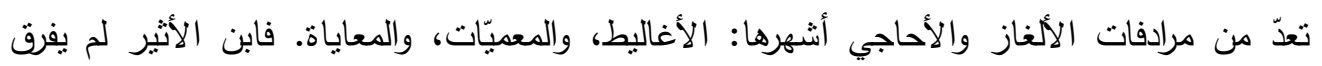

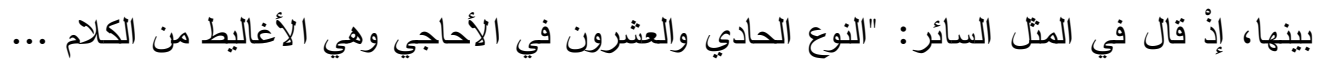

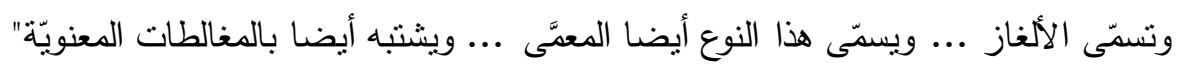

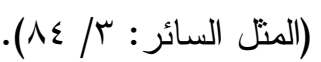

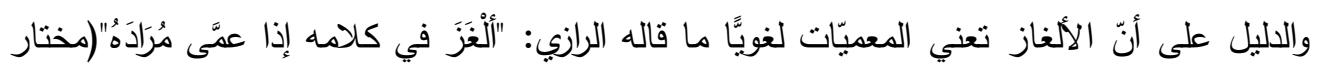

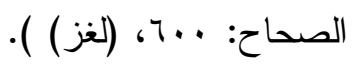

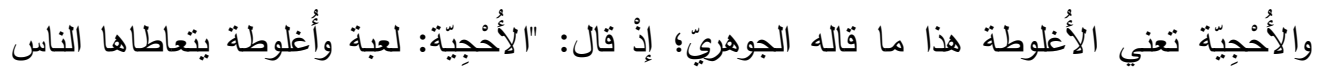

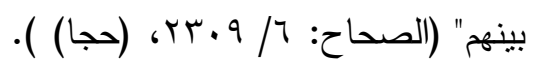

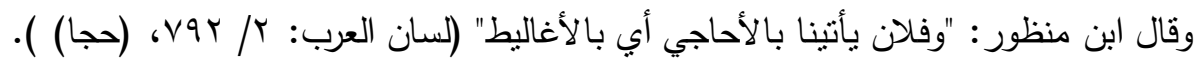

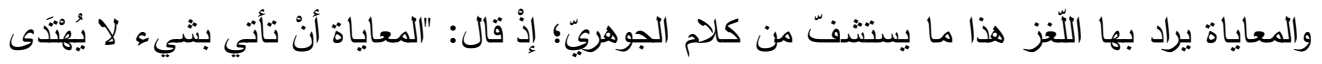

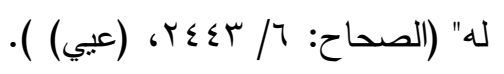

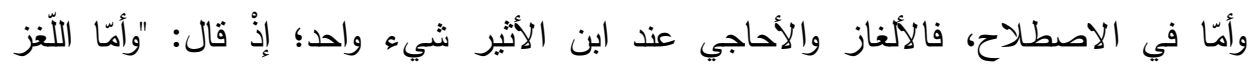

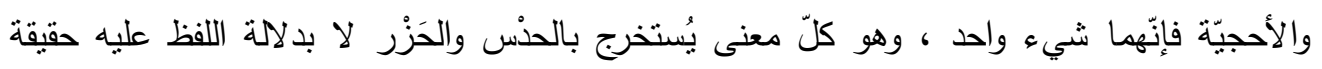

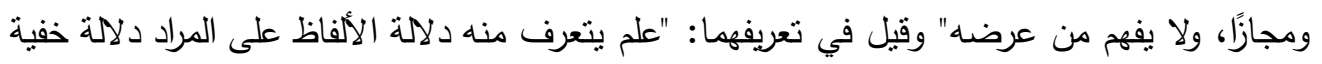

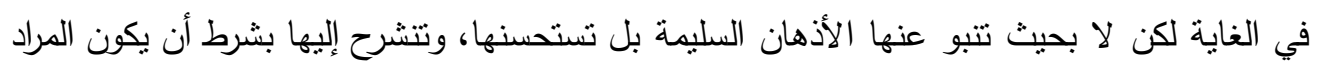

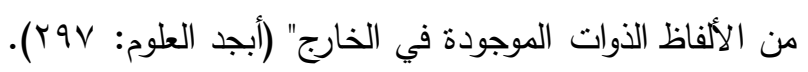

1 ـ الجمع :

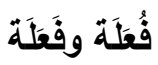

يجمع على فُعَلة - بضم الفاء وفتح العين - ماجاء مفردة على فاعل شرط اعتلال لامه نحو

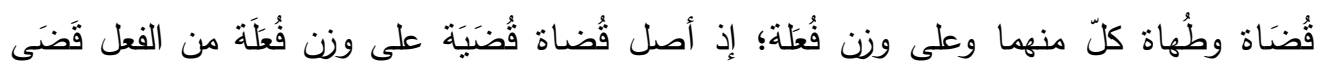

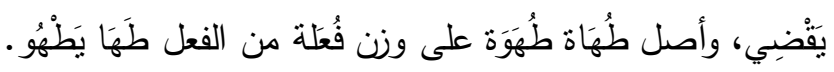


العدد الثاني والأربعون

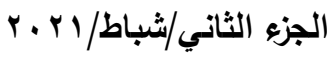

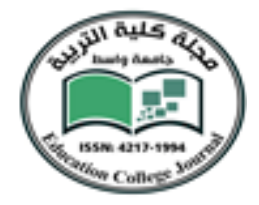

قلبت الياء في الأول، والواو في الثاني ألفاً لتحركها، وانفتاح ما قبلها؛ إذ نوزن الكلمة على صورتها الأصلية قبل حدوث الإعلال بالقلب (ينظر : التبصرة والتنكرة ب / 9797).

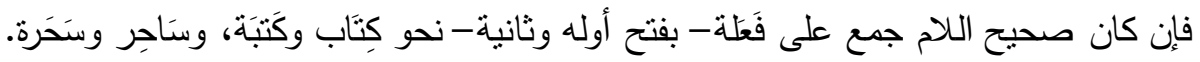

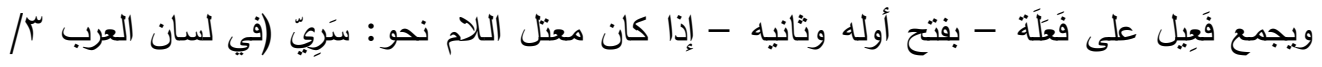

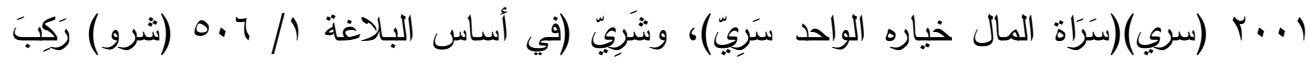
شَرَيَّا أي فرساً مختاراً)؛ إذ يقال في جمعهما سَرَاة، والأصل سَرَبَة، وشَرَرَبة، قلبت الياء فيهما ألفًَا لتحركهما وانفتاح ما قبلهما. وما ذكرناه ألغزه الزمخشريّ بقوله: "أخبرني عن فاعل جُعِعَ على فُعَلة، وعن فعيل جُمِعَ فَعَلَة"

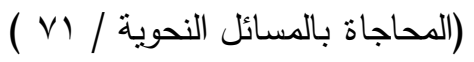

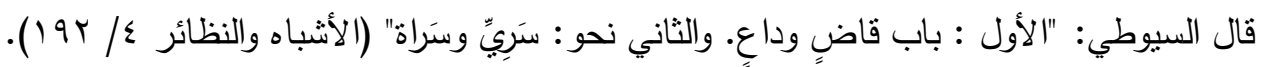

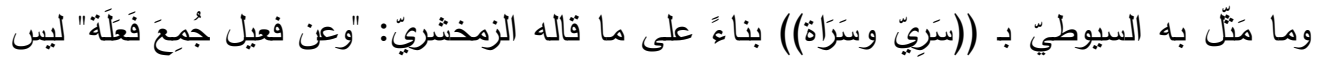

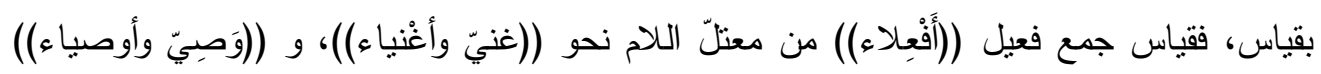

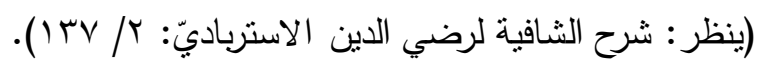
ما يجمع بالألف والتاء. ذكر الزمخشريّ لُغْزاً أراد حلّه لمن يقرأه إذ قال: "أخبرني عن اسم من أسماء العقلاء لا يجمع إلاّ بالألف والتاء" (المحاجاة بالمسائل النحوية عج أ) . فقوله من أسماء العقلاء يريد به الإنسان نحو "طلحة" فهو علم لمذكر عاقل مختوم بالتاء؛ إذ يجمع بالألف والتاء، فيقال: "طلَحات"- بفتح اللام (ينظر: الألغاز النحوية طبيعتها وقيمتها في التراث

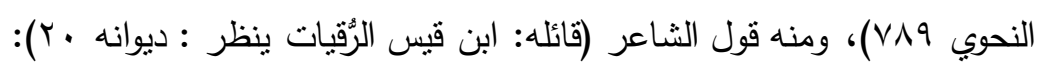

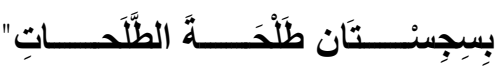

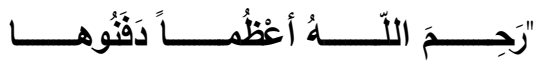

وقال الزمخشريّ: "أخبرني عن واحد من الأسماء ثُّيّي مجموعًا بالألف والتاء" (المحاجاة بالمسائل

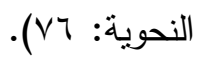
يريد الزمخشريّ أنَّ ما جمع بالألف والتاء نحو تَمْرات ومُقْبلات، فضلاً عن أذرعات، إذ يجوز تثنيتها، فيقال: تمراتان، ومقبـاتان، وأذرعاتان. 
العدد الثاني والأربعون

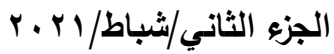

\section{جامسعة واسـط كليط}

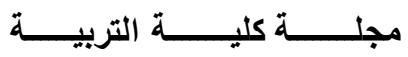

وهناك ألفاظ مذكرة لكنّها لا تجمع جمع مذكر سالماً وهي نوعان: أسماء، وصفات، فالأسماء نحو

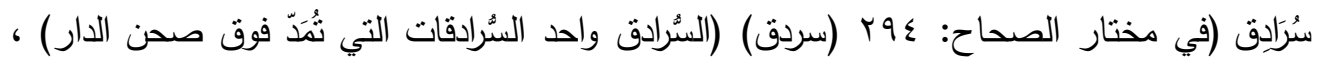

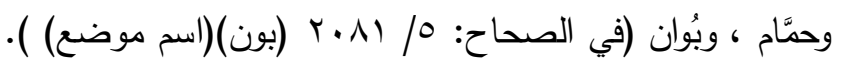

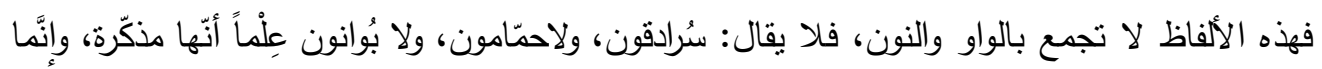

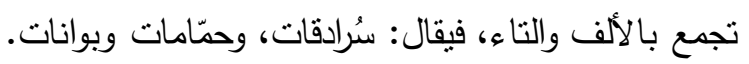

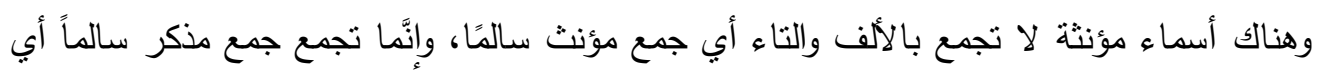

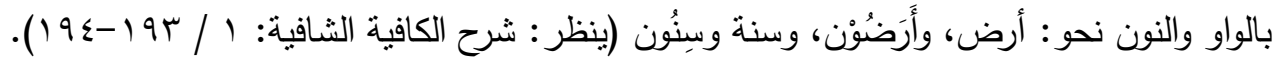

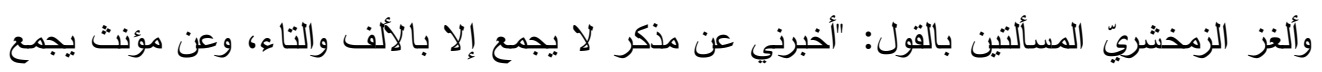

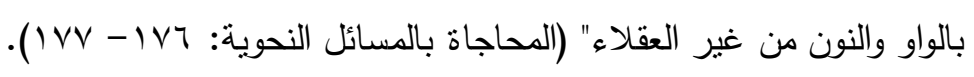

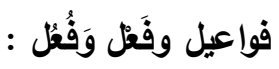

مِّا يجمع على فواعيل ما كان مفرده على فاعولة نحو طاحونة وطواحين، وقارورة وقوارير ، وطواويس جمع طاوس على وزن فاعول، وجاموس، وجواميس ويجمع على فواعيل ماجاء مواء مفرده

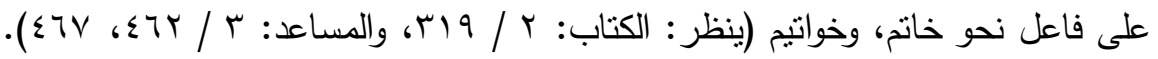

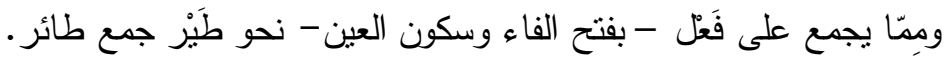

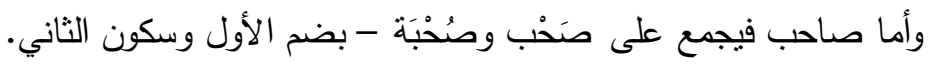

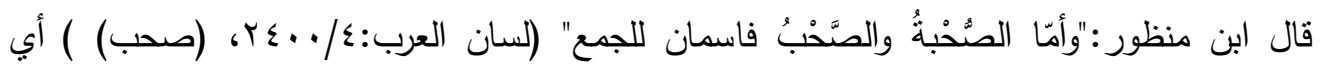

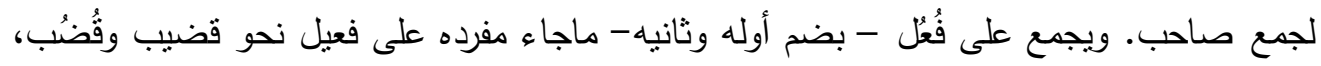

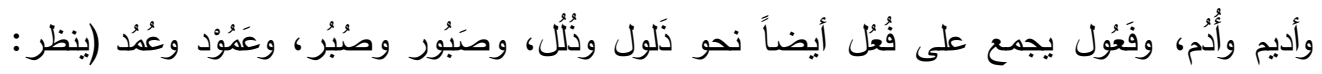

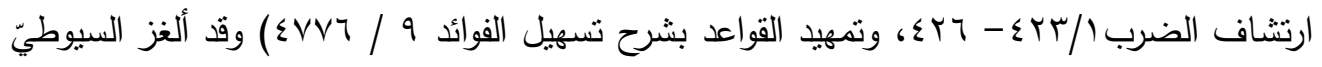

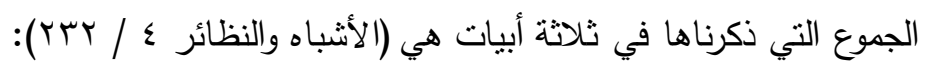
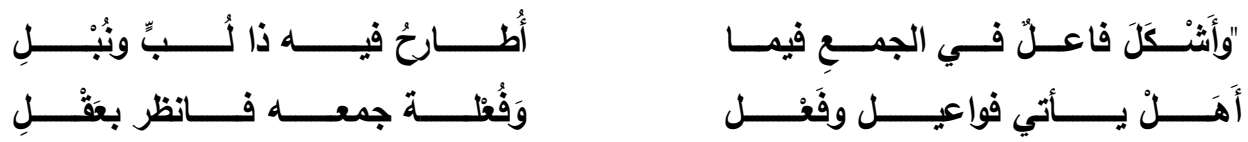

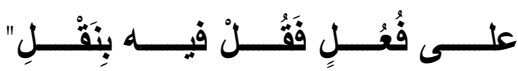

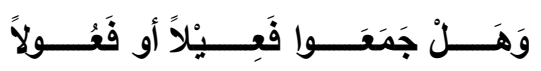

فذكر في البيت الأول وزن فاعل والذي يجمع على فواعيل، وفَعْل، وفُعَلَّة التي ذكرها في البيت الثاني. وذكر في البيت الثالث ما يجمع على فُعُل - بضمنين - وهو فعيل، وفَعُول. 
العدد الثاني والأربعون

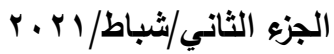

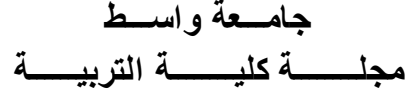

وهذا ما مثتّنا له بأمنتلة وافية.

من المصطلحات الموجودة والمتداولة في باب الجموع: اسم الجمع، واسم الجنس الجمعي والفرق

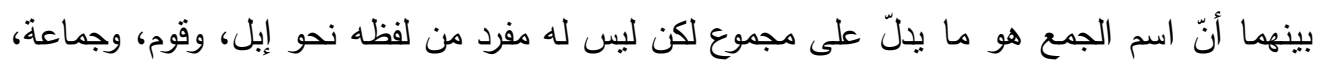
ورهط.

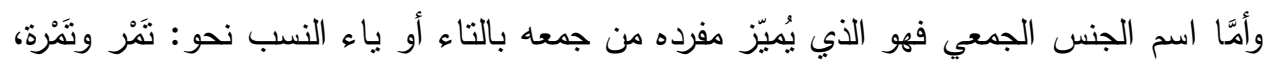

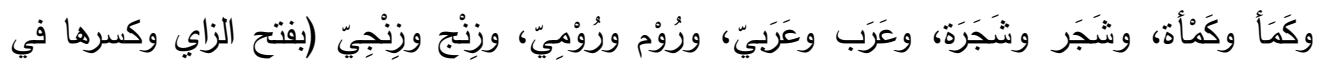

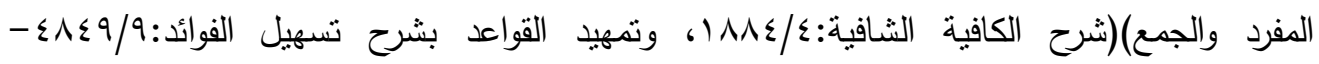
. ( $\{10$.

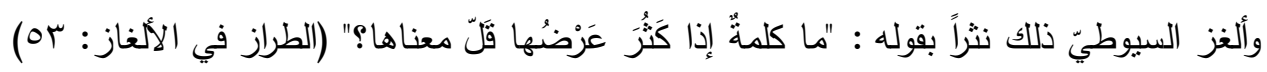
فكانت إجابته "أردت .... الاسم الجنس الجمعي إذا زيد عليه التاء نقص معناه، وصار واحداً كَتَمَّر

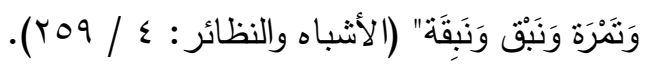

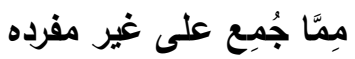

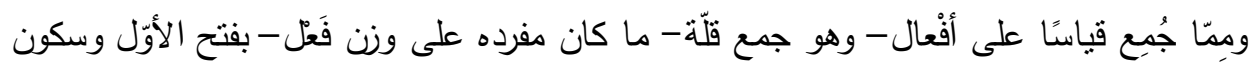

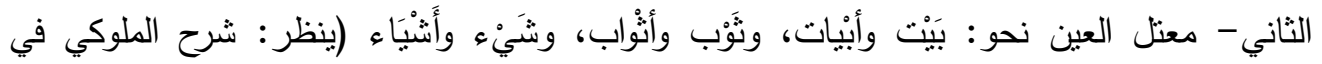

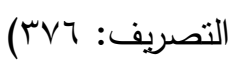

فأَنَّناء جمع على وزن أفعال مفرده شيْء على وزن فَعْل. وهو ما أثنتتاه بناءً على القاعدة الصرفية. ولُغزز جمع هذه اللفظة فيما قاله السيوطيّ:

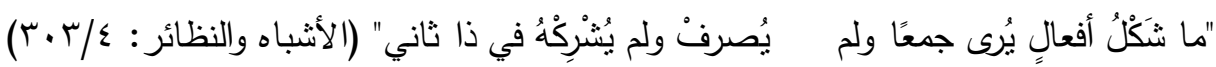

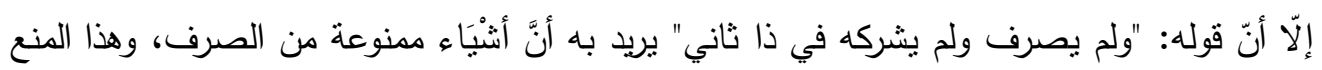

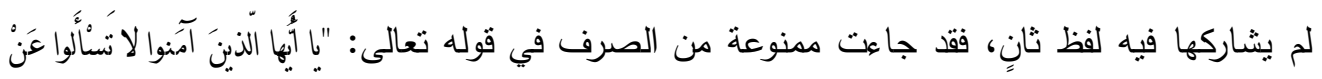

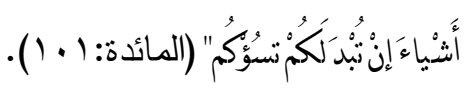

وإنّما منعت من الصرف نتيجة لاختلاف العلماء في وزنها الذي ليس على ظاهره. وهو المانع

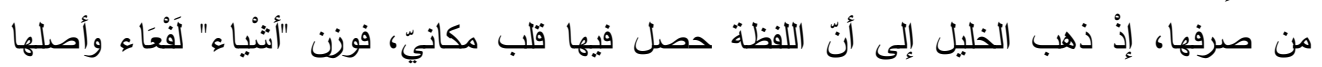

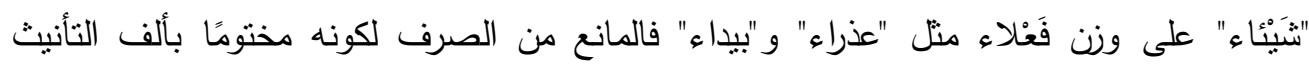

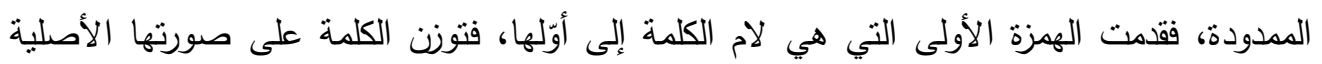

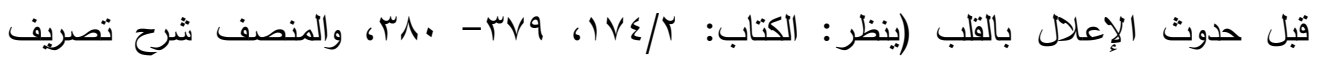


العدد الثاني والأربعون

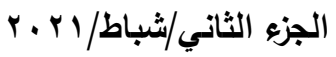
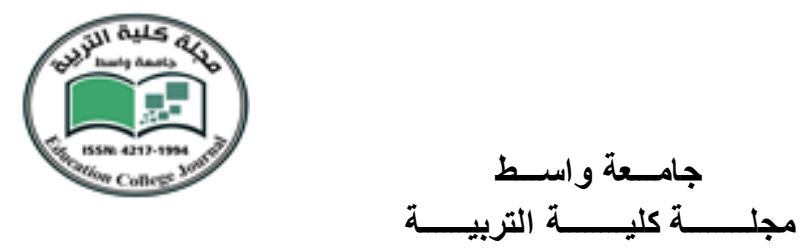

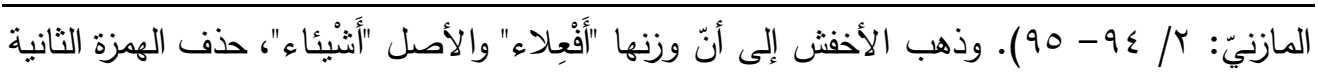

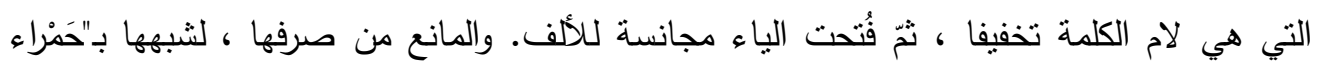

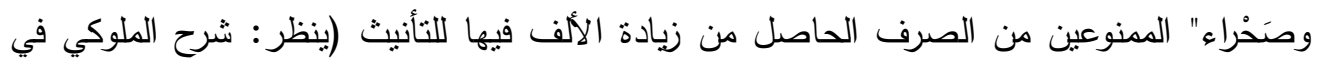

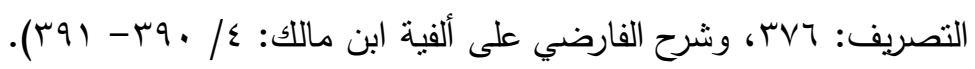

بين الجمع والإفراد من الألفاظ التي وردت في اللغة وتتعامل معاملة المفرد تارة، ومعاملة الجمع تارة أخرى كلمة

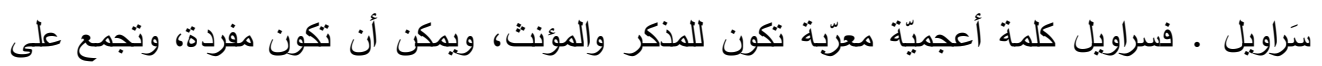

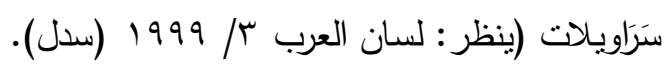

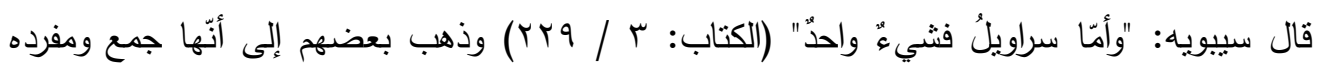

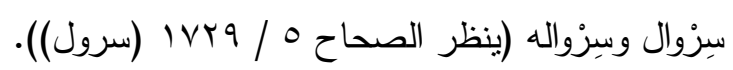

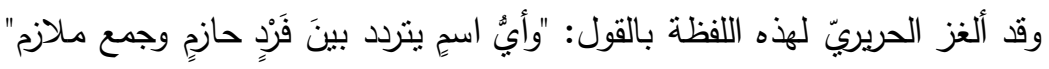

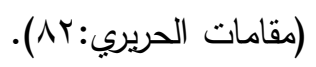

ووصفُ الحريريّ السروال بالحازم، وهي كناية عن الحزام الذَي يَثُدُ وَسَطَ الإنسان، وهو خَصْرِهُ

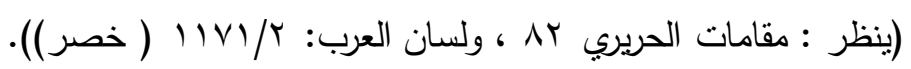
ومن الألفاظ التي نكون للواحد، والاثثين وللجمع قُلْك - بضم أولات أوله وسكون ثانيه.

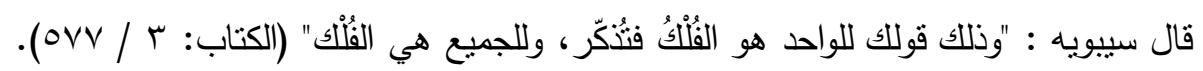

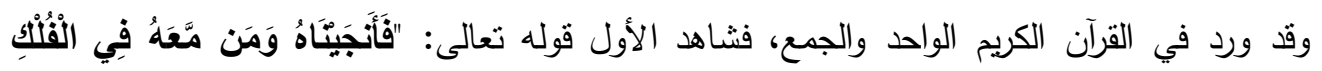

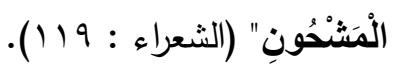

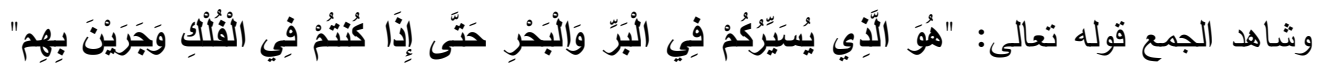

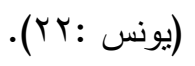

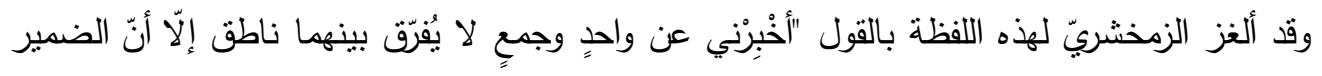

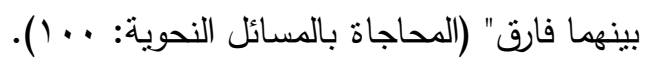

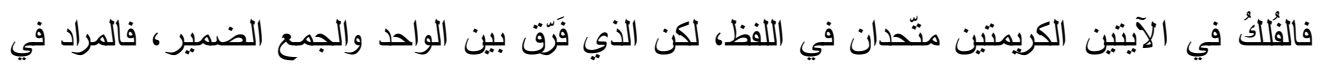
الآية الأولى سفينة واحدة، وفي الآية الثانية مجموعة سُفْنُ. 
العدد الثاني والأريعون

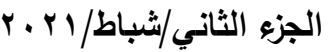

\section{جامسعة واسـط كليط}

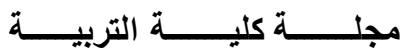

r - إبدال مصاحبه قلبان مكانيان

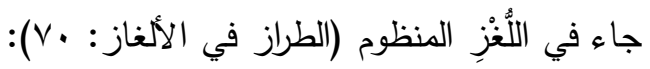

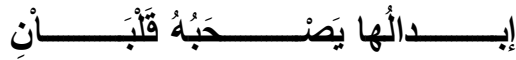

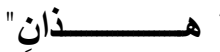

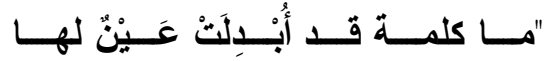

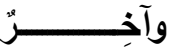

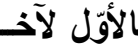

يريد اللاغز أنَّ هناك كلمة يحصل فيها إبدال وهذا الإبدال مصحوب بقلبين مكانيين، والكلمة التي يحصل فيها هذا هي جمع ناقة، ونقول: لِّ ناقة جمعان الأول جمع كثرة وهو نُوْق على وزن فُعْل - بضم الأول، وسكون الثاني، وهذا لا إعلال فيه ولانقل. والجمع الثاني جمع فلة وهو أنْوُق على وزن أَفْعل (بفتح الأول وسكون الثاني وضم الثالث)، وهذا

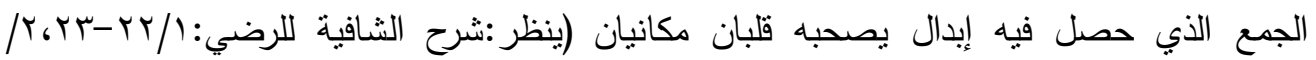
$:(1 \cdot 7$ فالأول : قلب عين الكلمة التي هي الواو الى اللام، فيقال أنْقُو، ثم تبدل الضمة كسرة ثم تقلب الواو ياء؛ لأنّها منطرفة مسبوقة بكسرة فيقال: أنْقي، ثم تعامل معاملة المنقوص نحو : داع وقاضٍ، ويقال فيها أَنْقِ وهذا القلب الأول. والقلب الثاني: نقل الياء الى فاء الكلمة، فتصبح اللفظة أينًْاً وبعد حصول هذين القلبين المكانيين، قال السيوطيّ: " فقد صار هذا الإبدال مرنبطاً بالقلب الأول الذي هو لآخر الكلمة، وبالقلب الثاني الذي هو لأولها. فهذان حالان للقلبين المذكورين" (الأشباه والنظائر:

\section{r - ب - وجود الكسرة وعدمها سيّان}

إنَّ أغلب الكلمات التي أحد أحرفها علّة يطرأ عليها تغيير في بعض تصاريفها فعلى سبيل المثال "مِيْزان، ومِيْعاد"، فالياء فيها منقلبة عن واو، والأصل مِوْازن من وَزَنَ، ومِوْعاد من وَعَد، وإنّما

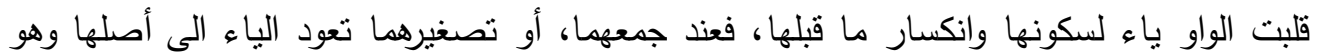
الواو لزوال السبب، فيقال: موازين في الجمع ومُوَيْنِن في التصغير وكذلك يقال في مِيْعاد: مَوَاعِيْ،

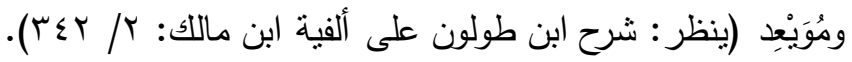

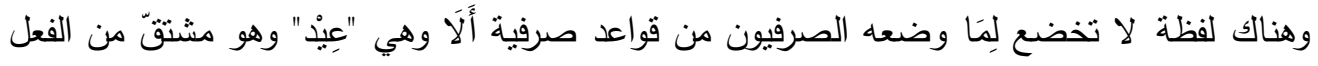
عاد يعود، فأصل عيد عِوْد، قلبت الواو ياء، لسكونها، وانكسار ما قبلها أبي مجانسة للكسرة، فعند 
العدد الثاني والأربعون

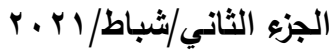

\section{جامسعة واسـط كليط}

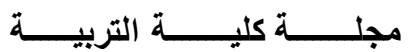

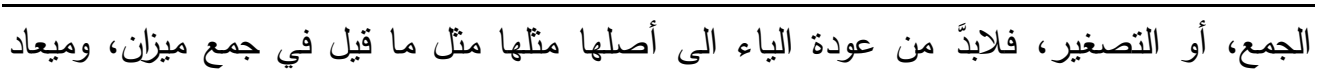

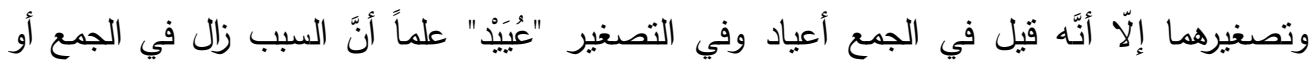

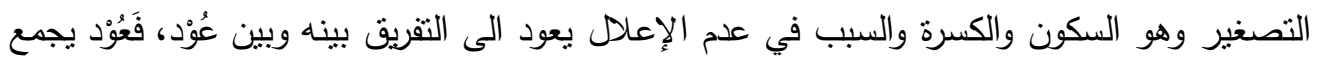

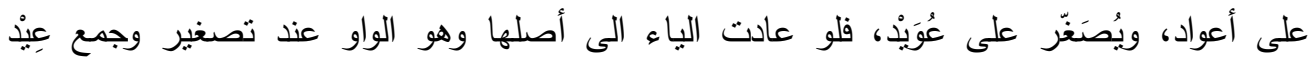

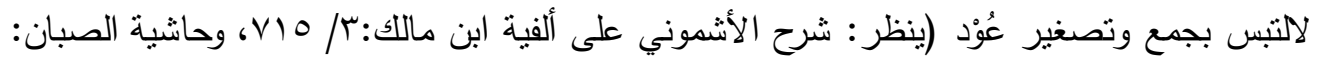
. (rT $r / \varepsilon$

ولهذه المسألة ألغز السيوطيّ نظمًا قال فيه:

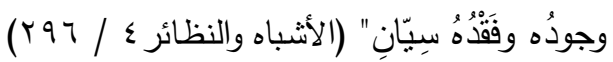

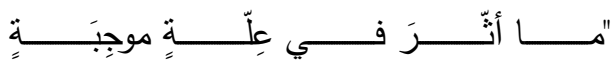

أي استواء وجود الكسرة التي كانت سببًا في قلب الواو ياء في "عِيْد" مع فقدانها في الجمع، ولم تَعُد الياء الى أصلها. ع - التصغير

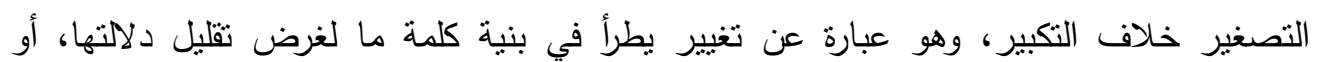

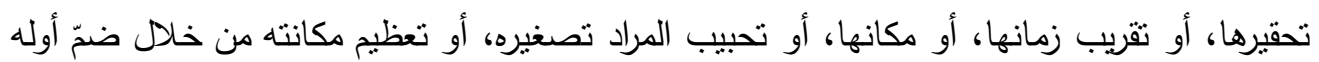

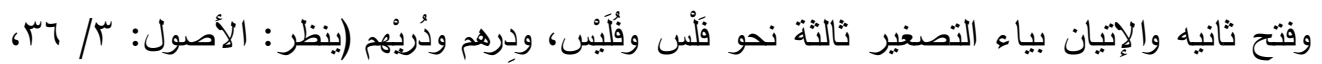

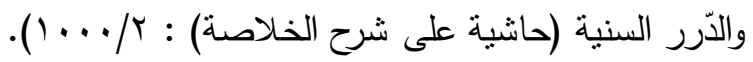

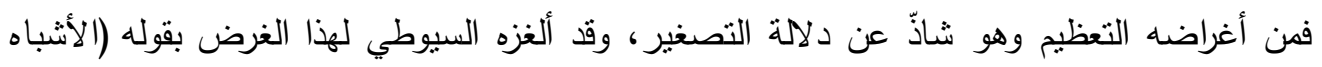

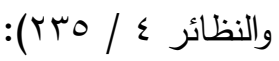

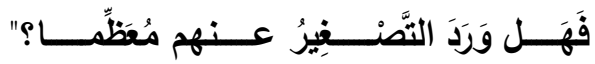

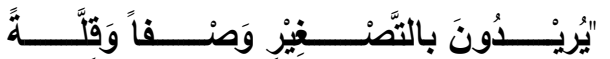
نحو دُوَبْهِيَة تصغير داهية للتعظيم (بنظر : تحصيل عين الذهب من معدن جوهر الأبب ساب) في قول الثاعر (قائلة لبيد بن ربيعة ينظر : ديوانه / ror):

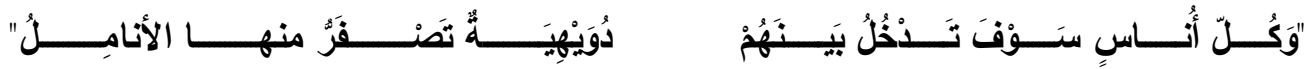

ويَظُنُّ بعضهم أن سُكَيْت (في الصحاح / / ror (سكت) (آخر ما يجيء من الخيل في الحلبة

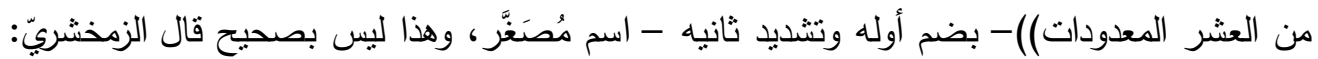

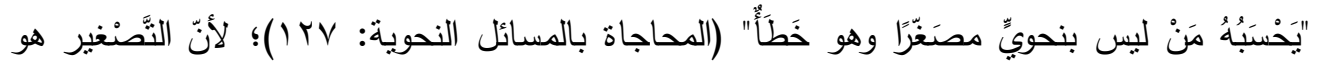


العدد الثاني والأربعون

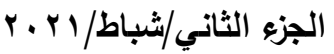

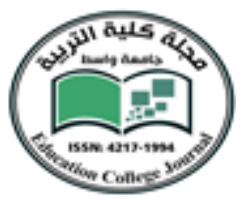

ضَمٌُم الحرف الأوّل، وفتح الحرف الثاني، ثمّ الإتيان بياء التصغير ثالثةً والياء في سُكِيْت، وإن كانت ساكنة، لكنّها وقعت رابعة؛ لأنّ الحرف الذي قبلها مضعّف أي عبارة عن حرفين. فقياس تصغير سُكّيْت سُكَيكيت، أو يُصَغَّر تصغير الترخيم، وهو حذف أحد حرفي التضعيف، فيقال سُكَبْتِ.

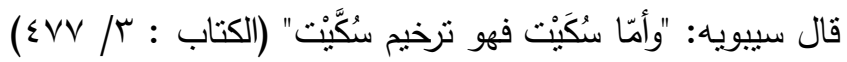

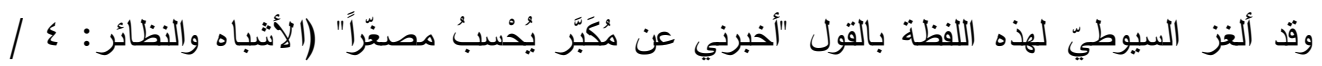
(Y) فالمصغّر، والذي يعامل معاملة المكبر - حُبْرُوْر - بضمّ أوله، وساكن ثانيه - وضمّ ثالثة - تصغير

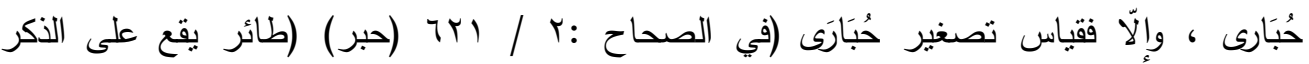
والأنثى )): حُبَيْرَى أو حُبِيِّر . فال السيوطيّ: "حُبْرُوْر هو في عداد المكبرات، وفي قول الأعرابي الذي سُئلِ عن تصغير الحُبَارى، فقال : حُبرُوْر " (الأشباه والنظائر : ع / / (Y). وهناك ألفاظ جاءت مصغّرة في أصل وضعها، ولايراد بها ذلك نحو: كُمَيْت (لون بين الأشقر والأسود

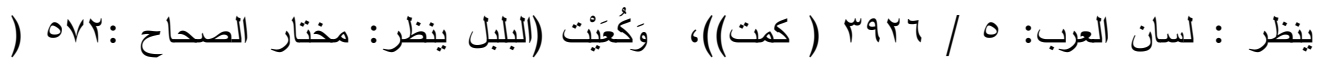
كعت () قال سيبويه: "هذا باب ما جرى في الكلام مصغَّرًاً وترك تكبيره ... ونلك قولهم : جُمَيْل وكُعَيت ....

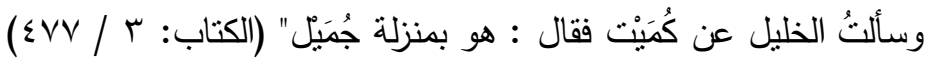

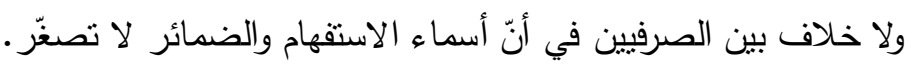
قال سيبويه : "واعْلَم أنَّ علامات الاضمار لا يحقّرن .... فمن علامات الإضمار هُو، وأنا ونحن

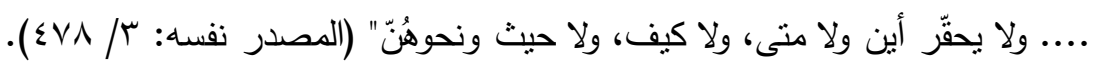
واللغز الذي يراد به مصغّر لا مكبَّرَ له وهو كُمَبْت وكُعَبَتْ، ومكبَّر لا مصغّر لله وهو الضمائر

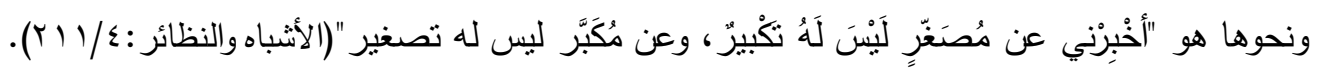

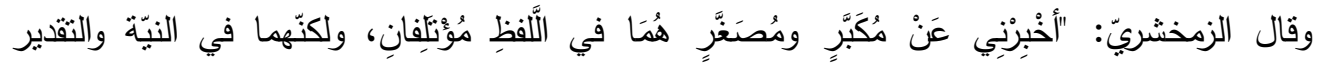
مُخْنَلَفَان" (المحاجاة بالمسائل النحوية: 77 (1) ). فما جاء مؤتلفًا في اللفظ ومختلفًا في النية (المعنى) مُبَيَطِر، وَمُسَنْطِر - بضمّ الأول، وفتح الثاني وسكون الثالث، وكسر الرابع فيها - ففيها زيادنان الميم والياء ، ولابدّ من حذف أحدهما عند التصغير ، ولا يجوز حذف الميم؛ لأنّها علامةٌُ من علامات اسم المفعول من غير الثتلاتي، فالياء أَوْلَى 
العدد الثاني والأربعون

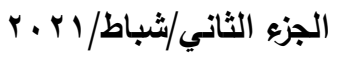

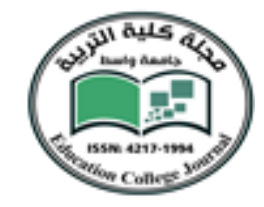

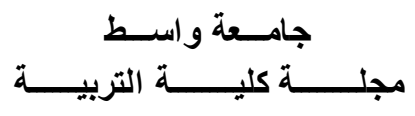

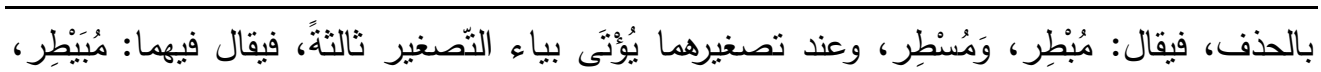

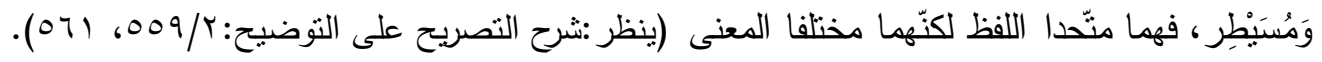

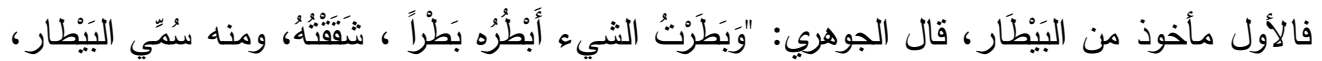

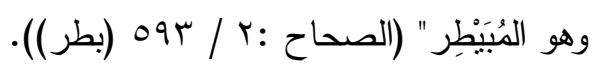

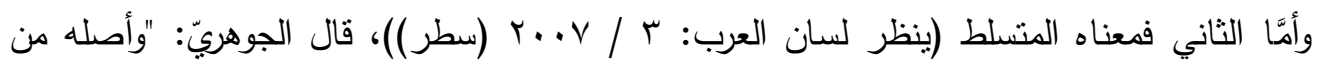

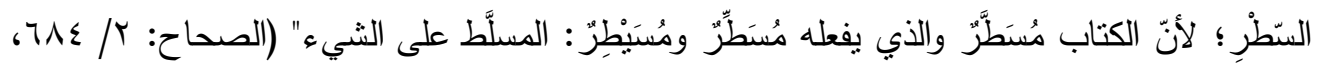
- (سطر) (s) وهناك ألفاظ يجوز في تصغيرها ثلاثة أوجه، مما جاءت على فَعْل وعينه ياء - بفتح الأول، وسكون الثاني - نحو بَيْت، وشَيْخَ ، إذ يقال فيها بُيَيْت، وَشُيَيْنخ على القياس، وهو الوجه الأول، ويكسر أوله شِيَيْخ ، وبيَيْتِ، وهذا هو الوجه الثاني. وأجاز الكوفيون قلب الياء واواً لمجانسة الضمة، فيقال شُوَيْخ وبُوَبْت. وهذا هو الوجه الثالث (ينظر :

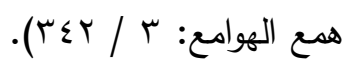
وقد ألغز السيوطيّ لما جاز فيه الأوجه الثناثة في التصغير، إذ قال: "وما اسم له -ـإنْ صغّروه-

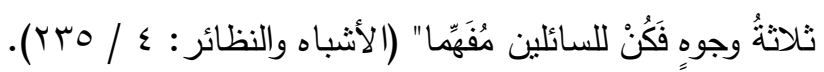
ه - النسب

النسب لغةً يعني الانتماء (ينظر : لسان العرب: 7 / 0 ــ ـ (نسب)). واصطلاحاً هو الإتيان بياء

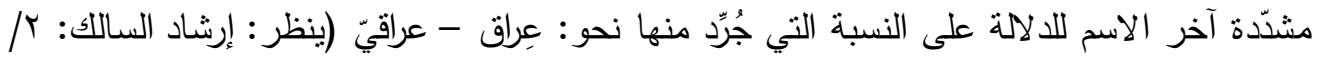
.$(949$ وهناك ألفاظ تلحق آخرها باء مشدّة، لكنّها ليست بياء النسب، من ذلك لفظ بُخْتِيّ - بضمّ أوله

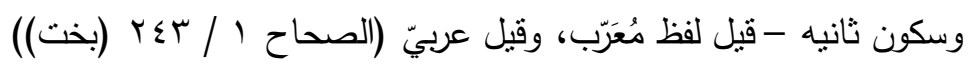

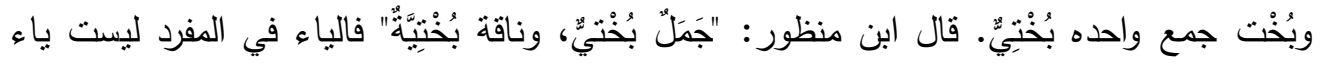

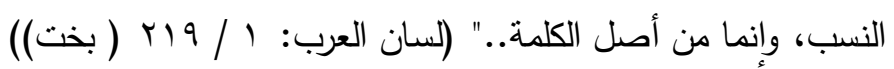
ولغزها هو : أَتَىَى لَفظُ العَلَاَمَةِة لَيْسَ يَخْفَى

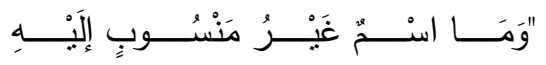

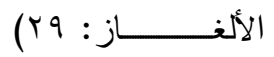
راز 
العدد الثاني والأربعون

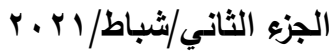

\section{جامسعة واسـط كلئ}

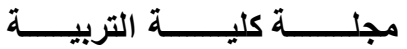

وقد يجمع بُخْتِيّ على بَخاتِيّ، وعند النسبة إليه لا بختلف عن جمعه، فكلّ ما هنالك حذفت الياء

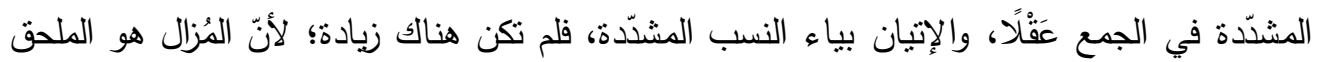

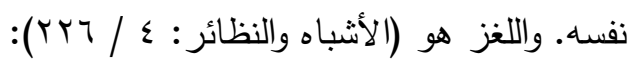

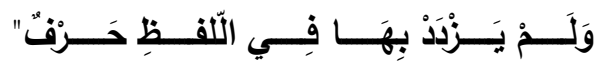

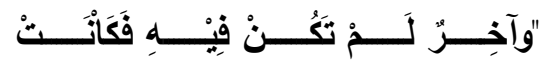

ولا يجوز النسبة الى الجمع، وإنمّا الى مفرده، ولهذا لا يجوز النسبة الى تَمرات وإنّما الى المفرد وهو

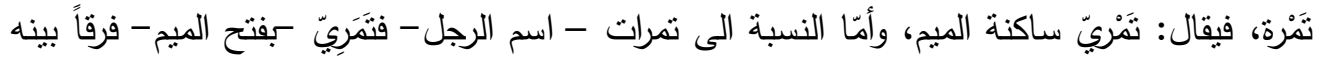

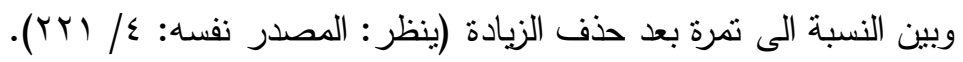

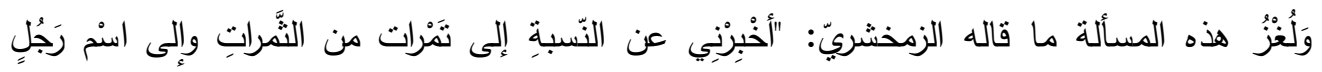

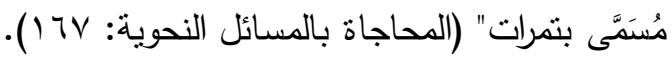

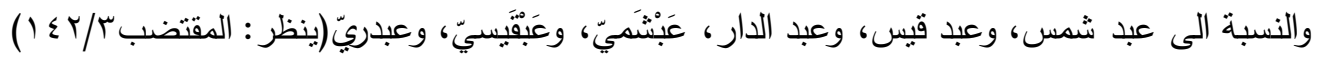

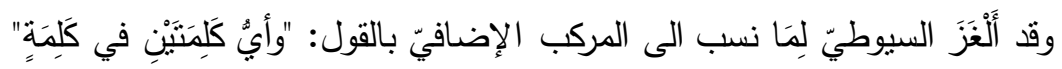

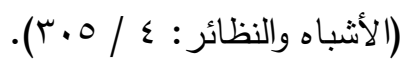

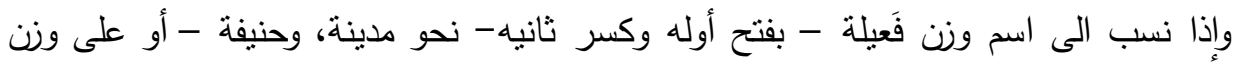

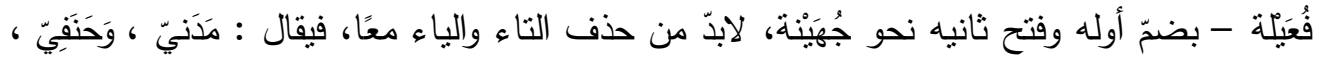

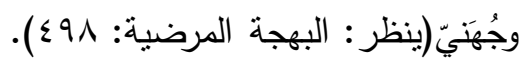

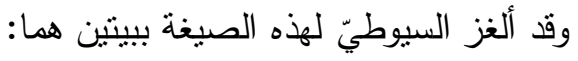

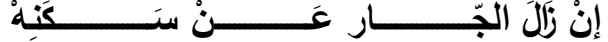

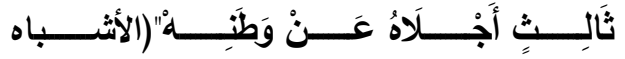

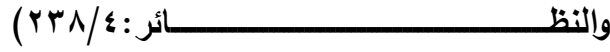
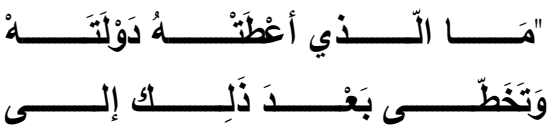

يريد بـ (ََأْلَ الجّار) تاء التأنيث التي هي جارّ ياء النسب، وقوله ونَخَطَّى .... إلى ثالث" يريد الياء.

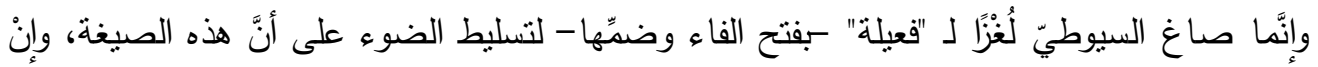

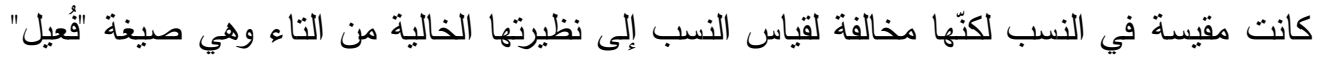

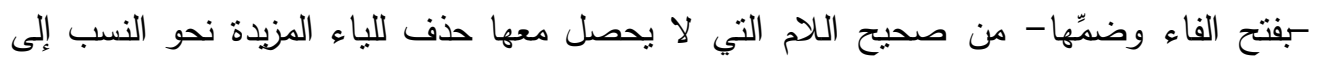

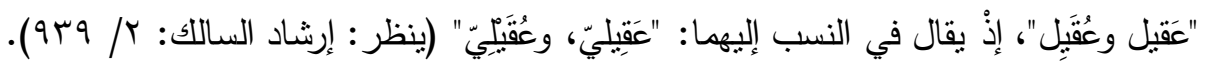
وقال أيضاً: 
العدد الثاني والأربعون

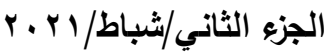

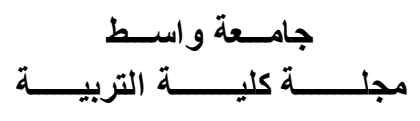

فإذاّا أُضُيف إليها ذُكِّر"

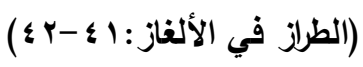

فقوله : فإذا أُضيف، يريد بالإضافة النسب، وهو مصطلح صرّح به سييويه، إذ قال: "هذا بابُ

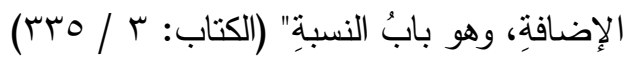

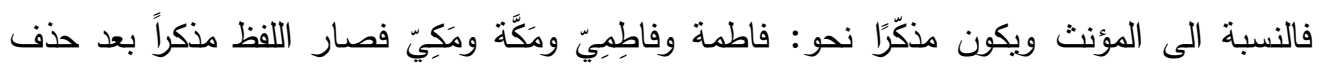

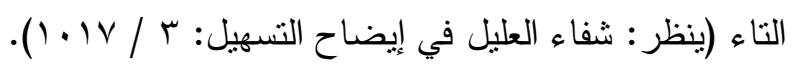

الخاتمة:

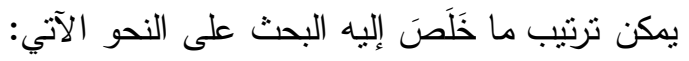

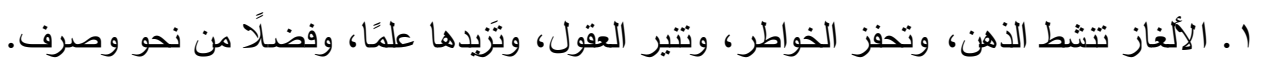

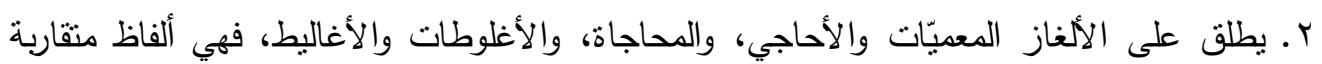
المعنى إن لم تكنْ ذات دلالة واحدة. بلمان.

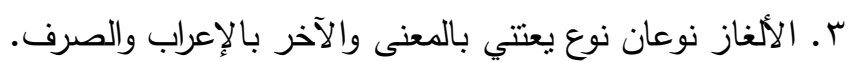

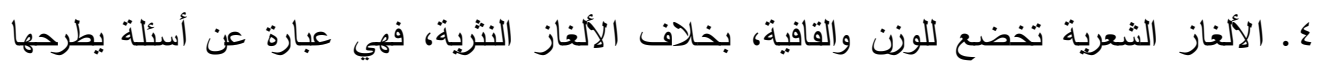

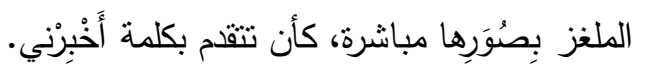
ه. لم تحظ الألغاز بالاهتمام والدراسة من قبل الدارسين، والتتقيب عنها في كتب الأقدمين، وتحقيق ما ألُّف فيها. 7 ا الألغاز وما بمعناها تبحث عن ألفاظ مختلفة، مخالفة لقواعد اللغة العربية، لما موجود فيها ما شذّ

$$
\text { عن القواعد النحوية والصرفية. }
$$

V. حظي موضوع الألغاز النحوية والصرفية عناية اللغويين، فقد ألّوا فيه كتبًا أمثال الفارقي

$$
\text { والزمخشريّ وابن هشام والسيوطيّ. }
$$

^. نعدّ الألغاز أسلوبًا من أساليب علماء اللغة في عرض التيّ القاعدة الصرفيّة، ومحورًا من محاور الدرس

$$
\text { الصرفيّ. }
$$

9. تقوم الألغاز على الغوض، وعدم الوضوح، والاختلاط، والتضليل وفي الغالب يقصد صاحب اللغز مخالفة القياس الصرفيّ بغية الأحجيّة. 
العدد الثاني والأربعون

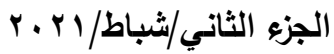

\section{جامسعة واسـط}

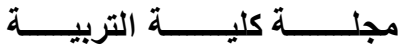

ثبت المصادر وإلمراجع:

• أبجد العلوم: القِتوجيّ ( أبو الطيب محمد صديق خان الحسيني ت V•rأهـ)، طا ، دار ابن حزم،

.5

ارتتثاف الضرب من لسان العرب، الأندلسي: أبو حيان (أثير الدين، أبو عبد الله، محمد ابن يوسف ت

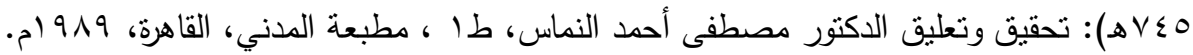

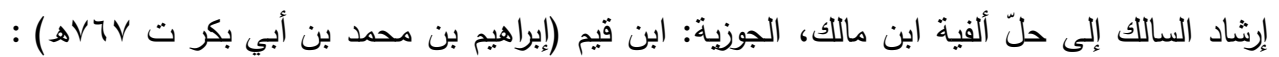

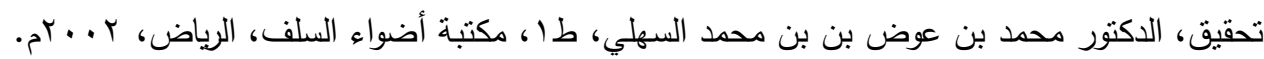

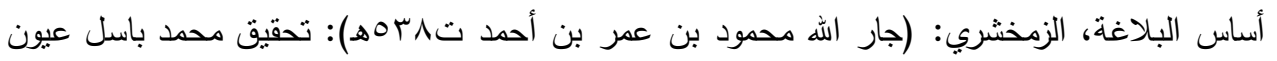
السود طا، دار الكتب العلمية، بيروت، 991 (م.

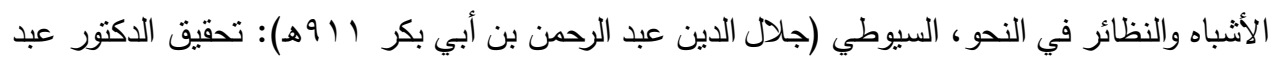

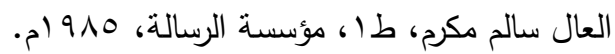

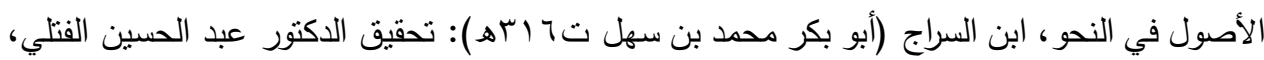

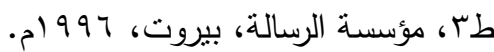
الألغاز النحوية طبيعتها وقيمتها في النزاث النحويّ: حولية كلية اللغة العربية بالمنوفية، الدكتور سماسم

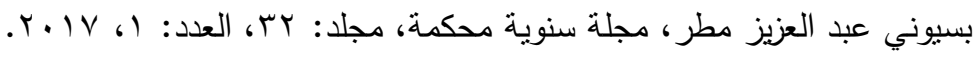

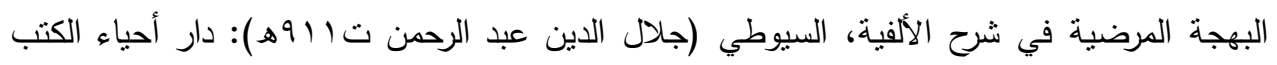

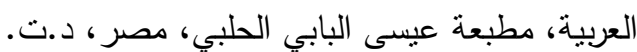

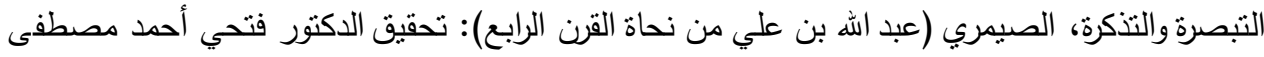

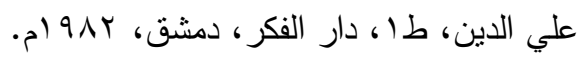

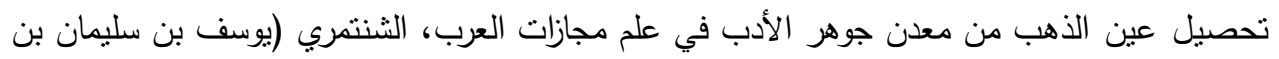

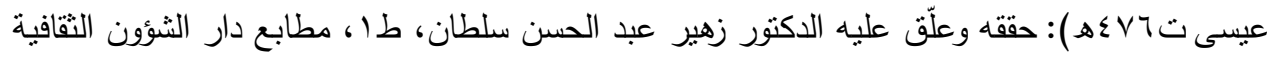

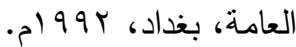

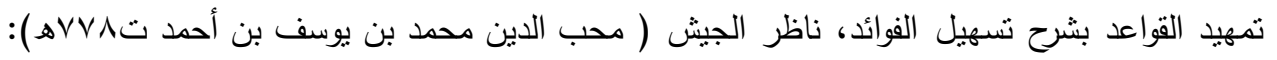
تحقيق ودراسة الأستاذ الدكتور علي محمد فاخر وآخرين، طا، دار السلام للطباعة والنشر، جمهورية التهاية

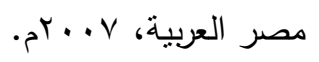

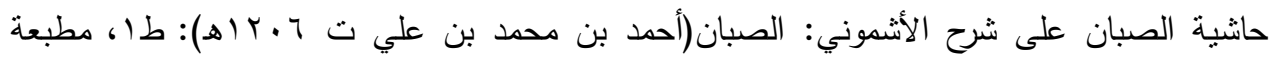

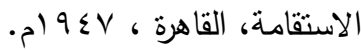

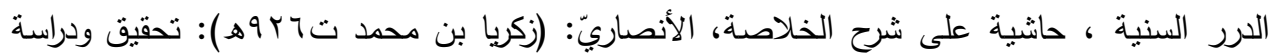

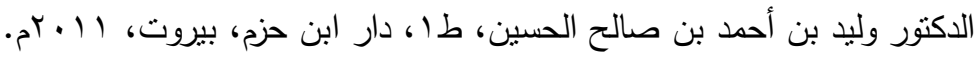


العدد الثاني والأربعون

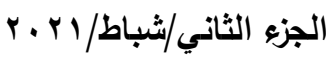

ديوان عبيد اله بن قيس الرقيات، الرقيات(عبيد اله بن قيس): تحقيق وشرح الدكتور محمد يوسف نجم، دار

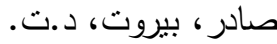

هديوان لبيد بن ربيعة، ابن ربيعة( لبيد): تحقيق الدكتور إحسان عباس، دار صادر ، بيروت، د.ت. شرح ابن طولون على ألفية بن مالك، ابن طولون(شمس الدين محمد بن علي ت بهوهـ هـ ): تحقيق الدكتور

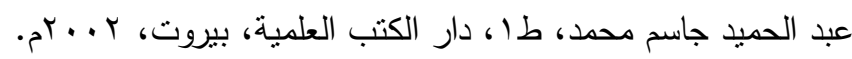

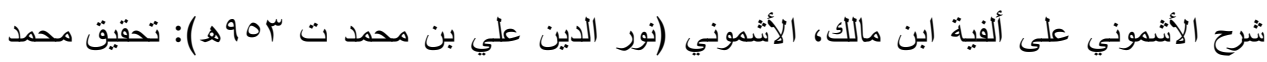
محيي الدين عبد الحميد، طا ، دار الكتاب العربي، بيروت، 900 ام.

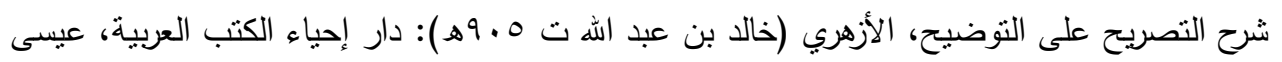

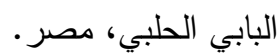
شرح الثافية، الاستربادي (محمد بن الحسن ت د1 آه): تحقيق محمد نور الحسن وآخرين، دار الكتب

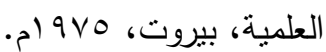

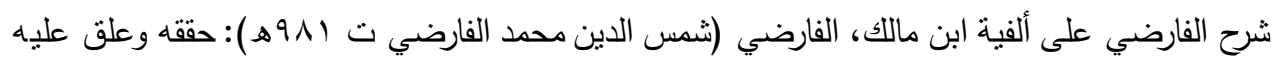

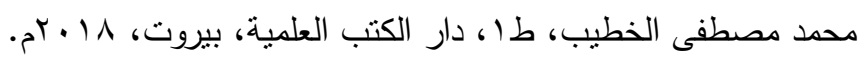

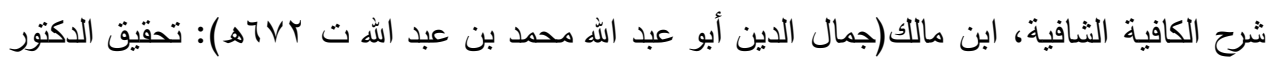

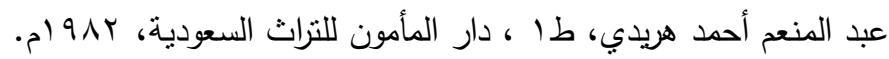
شرح الملوكي في التصريف، ابن يعيش (موفق الدين يعبش بن علي بن يعيش ت ب ؟ Tهـ): تحقيق الدكتور

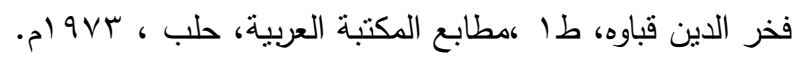
شفاء العليل في ايضاح التسهيل، السليلي (أبو عبد الله محمد بن عيسى ت): دراسة وتحقيق الدكتور

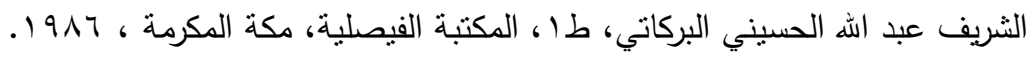
الصحاح ( تاج اللغة وصحاح العربية)، الجوهري (أبو نصر اسماعيل بن حماد ت سوسه): تحقيق أحمد الهد

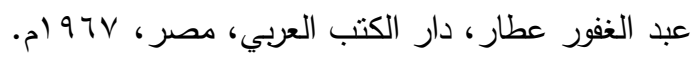

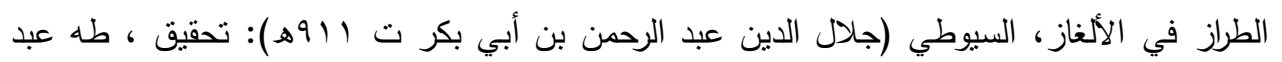

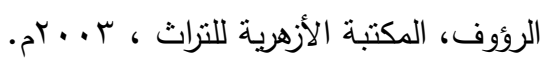
الكتاب، سيبويه (أبو بشر عمرو بن عثمان بن قنبر •1 الهـ): تحقيق وشرح عبد السلام محمد هارون، عالم الكتب، بيروت، د.ت دابك. لسان العرب، ابن منظور (أبو الفضل جمال الدين محمد بن مكرم ت Iالهـ): دار صادر، بيروت، . 907 • المثل السائر في أدب الكاتب والثاعر ، ابن الأثير (نصر الله بن أبي الكرم محمد بن محمد بن عبد الكريم ت T Y Tهـ): قدمه وعلق عليه الدكتور أحمد الحوفي، والدكتور بلوي طبانة، دار النهضة، القاهرة، د.ت. 
العدد الثاني والأربعون

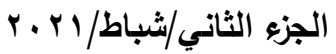

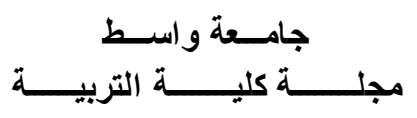

• المحاجاة بالمسائل النحوية، الزمخشري (جار الله أبو القاسم محمود بن عر ^بهـه): تحقيق الدكنورة

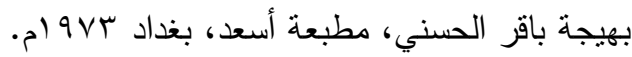

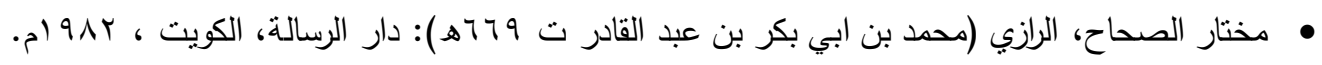

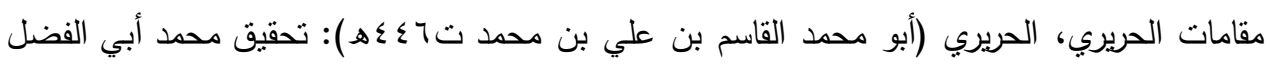
إبراهيم، المكتبة العصرية، بيروت، بو 99 ام.

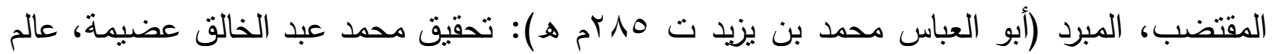
الكتب ، بيروت. • همع الهوامع في شرح جمع الجوامع، السيوطي (جلال الدين عبد الرحمن بن أبي بكر ت (1)): تحقيق

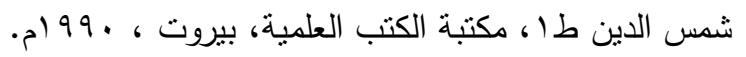

